\title{
THE EFFECT OF ADDITION OF LIMESTONE POWDER AND GYPSUM AS ISOLATOR MEDIA ON LOW CARBON STEEL SMAW WELDING
}

\author{
Muh Anhar ${ }^{*}$, Betti Ses Eka Polonia ${ }^{2}$ \\ Politeknik Negeri Ketapang ${ }^{1,2}$ \\ anhar_dol@yahoo.com \\ betti.polonia@gmail.com
}

Received : 20 April 2021, Revised: 09 May 2021, Accepted : 09 May 2021

*Coresponding Author

\begin{abstract}
Metal connection due to heat with or without the influence of pressure or metallurgical bonds caused by attractive forces between atoms. DIN (Deutsche Industrie Normen) state that metallurgical bonding of metal or guide metal joints in a melted or liquid state. This study aims to determine the effect of limestone powder and gypsum as an insulating medium in SMAW (Shielded metal arc welding) welding. This study using experimental methods with SMAW welding. Welding metal cooled with limestone media has a harder hardness than gypsum and air media, which is limestone has a thermal conductivity value of $3.897 \mathrm{~W} / \mathrm{m}^{\circ} \mathrm{C}$. In comparison, gypsum has a thermal conductivity value of $1.39 \mathrm{~W} / \mathrm{m}^{\circ} \mathrm{C}$, and air has a thermal conductivity value of $0.023 \mathrm{~J} / \mathrm{ms}^{\circ} \mathrm{C}$, so limestone is a better insulator than gypsum and air. The greater the conductivity value of the object, the better the thermal conductivity of the metal and the more complicated the weld metal and the lower the thermal conductivity value, the softer the metal hardness, limestone has a thermal conductivity value of $3.897 \mathrm{~W} / \mathrm{m}^{\circ} \mathrm{C}$ while gypsum has a thermal conductivity value of $1,39 \mathrm{~W} / \mathrm{m}^{\circ} \mathrm{C}$ and air have a thermal conductivity value of $0.023 \mathrm{~J}$ $/ m s^{\circ} \mathrm{C}$, proving that the lower the conductivity value, the hardness of the weld metal is getting softer, but in the HAZ section it proves that the lower the conductivity value, the more complex the hardness in the HAZ section.
\end{abstract}

Keywords : SMAW, limestone isolator dan gypsum, low carbon steel.

\section{Introduction}

Process of joining metals together due to heat with or without the influence of pressure or metallurgical bonds created by attractive forces between atoms. The welding definition based on DIN (Deutsche Industrie Normen) is a metallurgical bond on a metal or guide metal joint in a melted or liquid state. Welding is the process joining of several metal rods by utilizing heat energy. The connection of two metals become one through heating or melting, where the two ends of the metal join with an arc of flame or heat. It makes the two the metal tip or plane is a firm mass area and not easy to separate. A popular type of welding is welding using electric arc welding (SMAW) and carbide welding (Oxy acetylene welding / OAW). The aim to determine limestone powder and gypsum's function, whether suitable as an insulating medium in SMAW (Shielded metal) welding. arc welding) in addition to cooling through the air. Thus, researchers formulate how to add lime powder and gypsum as an insulating medium in SMAW (Shielded metal arc welding) welding.

\section{Literature Review}

The connection of two metals into one made by heating or melting, where the two ends are melted or melted with an arc of flame or heat obtained from an electric flame arc (burning gas). Both ends or metal fields become a strong mass field and are not easily separated. Two types of welding are popular in Indonesia, namely welding using an electric arc / Shield metal arc welding (SMAW) and Oxyacetylene welding (OAW). The selection of the proper welding current parameters affects the strength and changes in the mechanical properties. The current used is too low will cause difficulty igniting the electric arc, and the resulting angle is unstable. The heat that 
occurs is not enough to melt the electrodes and the base material, resulting in uneven welding teeth and less penetration.

Conversely, if the current is too high, the electrode will melt too quickly and result in a broader weld surface and deeper penetration. Several studies that have approached the above problems include; By using the Neutron Diffraction (ND) technique, the results show that a very high heat input will slow down the cooling rate. Using the Factorial Experiment method, the research results obtained: the current magnitude and volume velocity of the protective gas flow in SMAW welding affect HAZ toughness(Budiarsa, 2008). The welding also using cooling with the SMAW method on the hardness of ST 37 carbon steel with ash cement powder media on 100 kgf Rockwell load(Anhar, 2019). In connection with the things stated above, the current strength change factor determines the heat input received by the metal during the welding process. And how significant the impact of these changes needs to be known as signposts in the welding method. The highest hardness value lies in the part of the specimen closest to the cooling water spray from the nozzle of specimen 3 with heat treatment at a temperature of $8700{ }^{\circ} \mathrm{C}$ with a holding time of 90 minutes which has a hardness result close to the standard ASTM test method A255 (Chandra, 2018) as well as that carried out in the study. The effect of heating temperature treatment on the welding results of the SMAW method on the hardness of the parent metal and the weld metal with the tested specimen's raw material hardness was 51.4 HRB.

At the point test, the heat treatment temperature of $900^{\circ} \mathrm{C}$ has a weld metal hardness value of $54.3 \mathrm{HRB}$ and HAZ 52.7 HRB, at a heat treatment temperature of $800^{\circ} \mathrm{C}$, the hardness of the weld metal is $52.6 \mathrm{HRB}$ and $\mathrm{HAZ} 52 \mathrm{HRB}$, while at $700^{\circ} \mathrm{C}$ the hardness of the weld metal is 48.2 HRB and HAZ 51.4 HRB(Helanianto, 2017). In welding with differences in temperature and temperature that occurs will experience diffraction, the effect of heating temperature on the hardness, microstructure, and V-bending spring back result on commercial steel plates thickness of $0.8 \mathrm{~mm}$. The research method used was an experimental laboratory method. The heat treatment showed temperature variations of 710,820 , and $9300 \mathrm{C}$ with a holding time of 60 minutes(Ruchiyat, et. al., 2019).

\subsection{SMAW (Shielded Metal Arc Welding)}

The primary metal is liquefaction due to heating from the electric arc in this welding. The electric arc generates from a welding machine. It occurs between the tip of the electrode and the surface of the workpiece. The electrodes used are in the form of a wire wrapped in a protective flux. During welding, this electrode will melt along with the parent metal and freeze together to become part of the weld seam. Removing the electrode metal occurs when the electrode tip melts and forms grains carried by the electric arc current that arises. A large electric current is used to molten metal grains to become smooth, and vice versa; when the current is small, the granules become large.

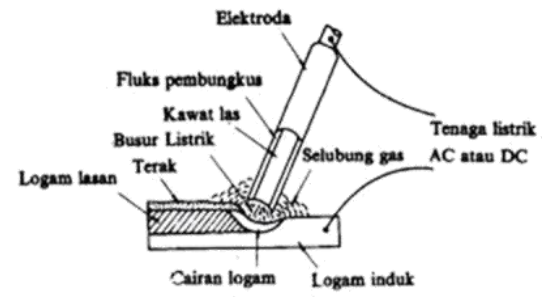

Fig. 1. SMAW Process

\subsection{Wrapped Electrode}

The electrode consists of two parts: the flux and the non-web part, which is the base for clamping the welding pliers. The flux's function is to protect the liquid metal from the air environment, produce a protective gas, stabilize the arc. The flux material used for the NK-68 E6013 type is iron powder and low hydrogen. This type is sometimes called the lime type. This type produces joints with low hydrogen content so that the connection sensitivity to cracking is very low, and the toughness is very satisfactory. 


\subsection{The Amount of Electric Current}

To produce even and smooth welds, the hand's speed to pull or push the electrodes when welding must be stable. The below condition moves the electrodes.

1) Precise and stable, resulting in a well-combined area with basic materials and a good permeate area.

2) Too fast, resulting in shallow weld seepage due to heating of the base fuel.

3) Too slow, resulting in a wide groove (see Figure 2). The motion of the electrode can cause damage to the weld side, especially if the base material is thin-weld.

\subsection{Welding Area Micro Structure}

The welding area consists of three parts: the weld metal area, the heat-affected zone, shortened to the HAZ, and the primary metal not affected by heat.

a. Welded metal area

The weld metal in the welding process melts and then freezes. The separation of the components causes an inhomogeneous structure. The form's inhomogeneity will generate a coarse ferrite structure and a top that reduces the toughness of the weld metal. In this area, the microstructure that occurs is the casting structure. The presence of columnar grains characterizes the microstructure in the weld metal. This structure begins with the parent metal and grows towards the center of the weld metal area.

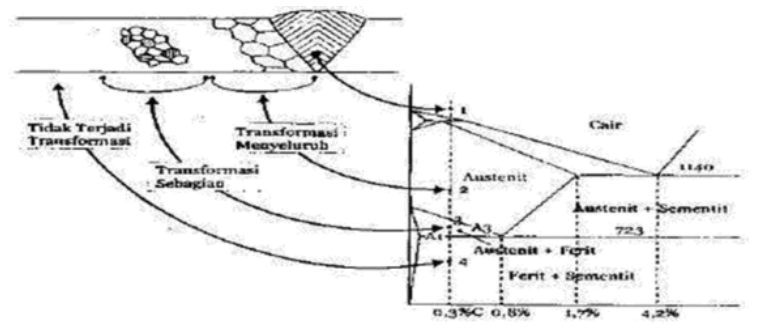

Fig. 2. The Direction Of Freezing Of The Weld Metal

The microstructure of the weld metal is usually a combination of the following microstructure:

- Ferrite grain boundaries formed first in the austenite-ferrite transformation typically include along the austenite boundary at a temperature of $1000-6500^{\circ} \mathrm{C}$.

- Widmanstatten ferrite or ferrite with an aligned second phase, this microstructure is formed at a temperature of $750-6500{ }^{\circ} \mathrm{C}$ along the austenite's grain boundaries, is significant, and overgrows so that it fills the grain surface.

- Acicular ferrite, intragranular shape with a small size and has a random orientation. Usually, this acicular ferrite is formed around a temperature of $6500{ }^{\circ} \mathrm{C}$ and has the highest toughness compared to other microstructures

- Bainite is a ferrite that grows from the austenite's grain boundaries and is formed at a temperature of $400-5000^{\circ} \mathrm{C}$. Bainite has a higher hardness than ferrite but lower than martensite.

- Martensite will be created if the welding process is high-speed cooling. This structure has rigid and brittle properties so that the toughness is low.

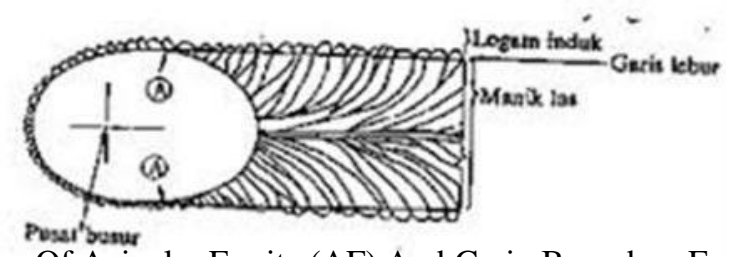

Fig. 3. Microstructure Of Acicular Ferrite (AF) And Grain Boundary Ferrite (GF)

Or Grain Boundary Ferrite

b. Heat affected zone (HAZ) 
The heat-affected zone (HAZ) is the base metal adjacent to the weld metal, which during the welding process undergoes a thermal cycle of rapid heating and cooling so that this area is the most critical of the weld joint. Visually, in the area close to the weld melting line, the metal structure is getting rougher.

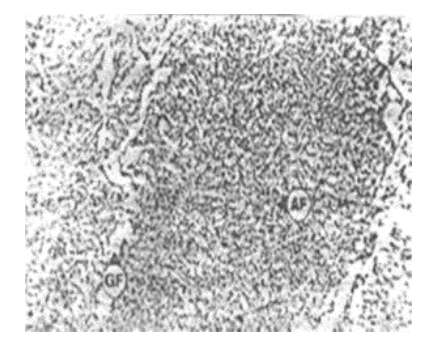

Fig. 4. Phase Transformation Of The Weld Metal

\subsection{Cooling phase}

According to DIN (Deutsche Industrie Norman), the definition of welding is a metallurgical bonding on a metal or metal alloy joint carried out in a melted or liquid state. Welding is the local joining of several metal rods using heat energy. Welding is joining two metals to the point of metal recrystallization, with or without using added materials. Its process using heat energy to melt the material that is being welded.

The weld metal area is the part of the metal that when the welding melts and then solidifies. The area of heat influence or HAZ is the base metal adjacent to the weld metal, which undergoes rapid thermal heating and cooling cycle during the welding process. The base metal, which is not affected by heat, is a part of the base metal where the welding's heat and temperature do not cause changes in structure and properties. There is a significant effect of variations in cooling media on the tensile test results on the products of welding ST52 steel material. This study uses ST52 material. The material is subjected to single vee joint welding, where upon completion of welding, the material is immersed in used oil cooling media, engine coolant, and lathe coolant for 30 minutes. After that, the material form according to ASTM E8 / E8M-11 standards for tensile testing. The results showed that the results of the tensile test on the specimens with used oil coolant media had the most excellent tensile strength value, which was $48.3 \mathrm{Kgf} / \mathrm{mm} 2$ with a small elongation value of $6.4 \%$. In contrast, the cooling medium produced the lowest value was a lathe coolant of $45.49 \mathrm{Kgf} / \mathrm{mm} 2$ with a significant elongation value of $9.61 \%$ (Zulkifli, et. al., 2020).

The use of cooling media in the post welding process will affect the tensile strength of a material. This study aims to determine how much the influence of using cooling media in post welding and which cooling media is appropriate. The process compares the tensile strength of each cooling media, namely the cooling media of water, water, and coolant. The use of cooling media is carried out after the welding process until the material ready to be welded reaches room temperature. Based on the experiments, post-welding cooling media affects the tensile strength of medium carbon steel with the highest effect on the water cooling media. The lowest is the air cooling media. Therefore, the choice of using cooling media significantly affects the tensile strength of medium carbon steel in the post-welding process(Zulhafril, et. al., 2020).

There is an effect of the cooling medium on the hardness of the weld metal, and HAZ (Heat Affected Zone) metal tested for hardness using the Rockwell method. This research was conducted on ST 37 low carbon steel material, which is welded using an E6013 electrode with a diameter of $2.6 \mathrm{~mm}$ with a direct connection, then cooling using white cement powder. Welding metal cooled with white cement powder media has a harder hardness because of white cement. It contains $\mathrm{C} 2 \mathrm{~S}$, which is difficult to hydrate and does not have heat properties. After testing at several points, the results obtained in the form of the average value of the raw material specimens were $48.3 \mathrm{HRB}$, welding without insulating media $=42.96 \mathrm{HRB}$, and $\mathrm{HAZ}=46.4 \mathrm{HRB}$. Samples using white cement powder $=47.65 \mathrm{HRB}$ and $\mathrm{HAZ}=48.2 \mathrm{HRB}$. It can be seen from this phenomenon, and white cement has a lower hardness value than air, where the HAZ on the 
hardness value in the air is $46.4 \mathrm{HRB}$, and the value in white semen was higher at $48.2 \mathrm{HRB}$ (Anhar \& Ruchiyat, 2020).

\section{Gypsum}

The white rock forms due to seawater deposition. Gypsum is the most common sulfate mineral on earth and most in sedimentary rocks, soft when pure. In the trading world, gypsum usually contains $90 \% \mathrm{CaSO}_{4} 2 \mathrm{H}_{2} \mathrm{O}$. Gypsum is a chemical compound containing two crystal molecules and is known as the chemical formula $\mathrm{CaSO}_{4} 2 \mathrm{H}_{2} \mathrm{O}$. In its pure form, gypsum is a white crystal and is gray, yellow, orange, or black if it is less refined. With heat treatment, pressure, mixing with other elements can produce various types of gypsum.

\section{Limestone}

Limestone found in nature is of various kinds or types. It's including calcite $\left(\mathrm{CaCO}_{3}\right)$, dolomite $\left(\mathrm{CaCO}_{3} \mathrm{MgCO}_{3}\right)$, magnesite $\left(\mathrm{MgCO}_{3}\right)$, siderite $\left(\mathrm{FeCO}_{3}\right)$, ankerite $\left(\mathrm{Ca}_{2} \mathrm{Fe}\left(\mathrm{CO}_{3}\right) 4\right)$, and aragonite $\left(\mathrm{CaCO}_{3}\right)$. The chemical composition is the same as calcite but differs in its crystal structure.

\subsection{Carbon Steel}

Carbon steel is an alloy between iron and carbon with small amounts of $\mathrm{Si}, \mathrm{Mn}, \mathrm{P}, \mathrm{S}$, and $\mathrm{Cu}$. The nature of carbon steel is very dependent on the carbon content. If the carbon content increases, the strength, and hardness will also increase. Therefore, carbon steels are grouped based on their carbon content.

\subsection{Rockwell Hardness}

Rockwell method Unlike the Brinell and Vickers method, where the hardness of a material is judged by the diameter or diagonal of the resulting trace, the Rockwell method is a hardness test with direct reading. Rockwell B's most common practice concerning ASTM E 18 using a steel ball indenter with a diameter of 1/16 inch and a load of $150 \mathrm{~kg}$, and Rockwell $\mathrm{C}$ using a diamond indenter with a load of $150 \mathrm{~kg}$. For soft materials using a penetrator used is a steel ball (Ball) which became known as scale $\mathrm{B}$, and for hard materials, the penetrator used is a cone of diamond (Cone) with a peak angle of $120^{\circ}$.

However, other Rockwell methods are also commonly used. Therefore the Rockwell hardness scale of material must be specified. For example, $82 \mathrm{HRB}$, which states that the material is measured on a B scale. Indenter 1/16 inch and a load of $100 \mathrm{~kg}$.

\section{Research Methods}

This study uses experimental methods, with SMAW welding and lime-gypsum insulators, to determine the effect of adding lime powder and gypsum as an insulating medium in SMAW welding (Shielded metal arc welding) and SMAW welding methods.

\section{Results And Discussions}

\subsection{Raw Material Testing Results Hardness Test on Rockwell Machines}

The hardness test results of the $3 \mathrm{~mm}$ thick low carbon steel plate were cut to a length of 150 $\mathrm{mm}$ and a plate width of $50 \mathrm{~mm}$.

Table 1 - Raw Material Testing Results

\begin{tabular}{|c|c|c|}
\hline Point & Area & Specimen \\
\hline & \multirow{9}{*}{$\begin{array}{l}\text { Low carbon } \\
\text { steel plate }\end{array}$} & Raw Material/Unit \\
\hline 1 & & $53 \mathrm{kgf}$ \\
\hline 2 & & $52 \mathrm{kgf}$ \\
\hline 3 & & $52 \mathrm{kgf}$ \\
\hline 4 & & $51 \mathrm{kgf}$ \\
\hline 5 & & $51 \mathrm{kgf}$ \\
\hline 6 & & $51 \mathrm{kgf}$ \\
\hline 7 & & $51 \mathrm{kgf}$ \\
\hline 8 & & $51 \mathrm{kgf}$ \\
\hline
\end{tabular}




\begin{tabular}{lc}
\hline$\frac{19}{9}$ & $51 \mathrm{kgf}$ \\
\cline { 1 - 1 } Average & $51 \mathrm{kgf}$ \\
\hline & $51,4 \mathrm{kgf}$ \\
\hline
\end{tabular}

Table 2 - Test Results for Welding Joints with Limestone Media and Parts Exposed to Heat Treatment or HAZ

\begin{tabular}{|c|c|c|c|}
\hline Point & Area & Limestone/unit & $\begin{array}{l}\text { Limestone } \\
\text { HAZ /Unit }\end{array}$ \\
\hline 1 & \multirow{10}{*}{$\begin{array}{c}\text { Welded } \\
\text { Joints with } \\
\text { Limestone } \\
\text { Media and } \\
\text { Parts } \\
\text { subjected to } \\
\text { Heat } \\
\text { Treatment or } \\
\text { HAZ }\end{array}$} & $48 \mathrm{kgf}$ & $45 \mathrm{kgf}$ \\
\hline 2 & & $44 \mathrm{kgf}$ & $45 \mathrm{kgf}$ \\
\hline 3 & & $45 \mathrm{kgf}$ & $45 \mathrm{kgf}$ \\
\hline 4 & & $48 \mathrm{kgf}$ & $44 \mathrm{kgf}$ \\
\hline 5 & & $46 \mathrm{kgf}$ & $46 \mathrm{kgf}$ \\
\hline 6 & & $48 \mathrm{kgf}$ & $47 \mathrm{kgf}$ \\
\hline 7 & & $50 \mathrm{kgf}$ & $48 \mathrm{kgf}$ \\
\hline 8 & & $50 \mathrm{kgf}$ & $48 \mathrm{kgf}$ \\
\hline 9 & & $53 \mathrm{kgf}$ & $47 \mathrm{kgf}$ \\
\hline 10 & & $50 \mathrm{kgf}$ & $46 \mathrm{kgf}$ \\
\hline & Average & $48,2 \mathrm{kgf}$ & $46,1 \mathrm{kgf}$ \\
\hline
\end{tabular}

Table 3 - Welding Connection with Gypsum Media

\begin{tabular}{|c|c|c|c|}
\hline Point & Area & $\begin{array}{l}\text { Gypsum/ } \\
\text { unit }\end{array}$ & $\begin{array}{c}\text { Gypsum HAZ/ } \\
\text { unit }\end{array}$ \\
\hline 1 & \multirow{10}{*}{$\begin{array}{c}\text { Welded } \\
\text { Joints with } \\
\text { Gypsum } \\
\text { Media and } \\
\text { Parts } \\
\text { Exposed to } \\
\text { Heat } \\
\text { Treatment or } \\
\text { HAZ }\end{array}$} & $47 \mathrm{kgf}$ & $52 \mathrm{kgf}$ \\
\hline 2 & & $46 \mathrm{kgf}$ & $50 \mathrm{kgf}$ \\
\hline 3 & & $45 \mathrm{kgf}$ & $45 \mathrm{kgf}$ \\
\hline 4 & & $50 \mathrm{kgf}$ & $50 \mathrm{kgf}$ \\
\hline 5 & & $50 \mathrm{kgf}$ & $50 \mathrm{kgf}$ \\
\hline 6 & & $45 \mathrm{kgf}$ & $48 \mathrm{kgf}$ \\
\hline 7 & & $45 \mathrm{kgf}$ & $45 \mathrm{kgf}$ \\
\hline 8 & & $46 \mathrm{kgf}$ & $50 \mathrm{kgf}$ \\
\hline 9 & & $45 \mathrm{kgf}$ & $50 \mathrm{kgf}$ \\
\hline 10 & & $46 \mathrm{kgf}$ & $51 \mathrm{kgf}$ \\
\hline & iverage & $46,5 \mathrm{kgf}$ & $49,1 \mathrm{kgf}$ \\
\hline
\end{tabular}

Table 4 - Welded Joints Without Isolating Media and Parts Exposed to Heat Treatment or HAZ

\begin{tabular}{|c|c|c|c|}
\hline Point & Area & $\begin{array}{c}\text { Weld } \\
\text { Metal/unit }\end{array}$ & HAZ/unit \\
\hline 1 & \multirow{10}{*}{$\begin{array}{l}\text { Welding } \\
\text { Connection } \\
\text { Without } \\
\text { Isolator } \\
\text { Media }\end{array}$} & $50 \mathrm{kgf}$ & $51 \mathrm{kgf}$ \\
\hline 2 & & $47 \mathrm{kgf}$ & $50 \mathrm{kgf}$ \\
\hline 3 & & $47 \mathrm{kgf}$ & $50 \mathrm{kgf}$ \\
\hline 4 & & $45 \mathrm{kgf}$ & $48 \mathrm{kgf}$ \\
\hline 5 & & $46 \mathrm{kgf}$ & $48 \mathrm{kgf}$ \\
\hline 6 & & $45 \mathrm{kgf}$ & $50 \mathrm{kgf}$ \\
\hline 7 & & $46 \mathrm{kgf}$ & $52 \mathrm{kgf}$ \\
\hline 8 & & $46 \mathrm{kgf}$ & $52 \mathrm{kgf}$ \\
\hline 9 & & $46 \mathrm{kgf}$ & $51 \mathrm{kgf}$ \\
\hline 10 & & $50 \mathrm{kgf}$ & $52 \mathrm{kgf}$ \\
\hline \multicolumn{2}{|c|}{ Average } & $46,8 \mathrm{Kgf}$ & $50,4 \mathrm{kgf}$ \\
\hline
\end{tabular}

\subsection{Raw Material Specimen}

The raw material of one of the test specimens that will be used for research and is used for comparison with welding test specimens with lime, gypsum, and air media, shows the hardness number of the raw material test specimens. 


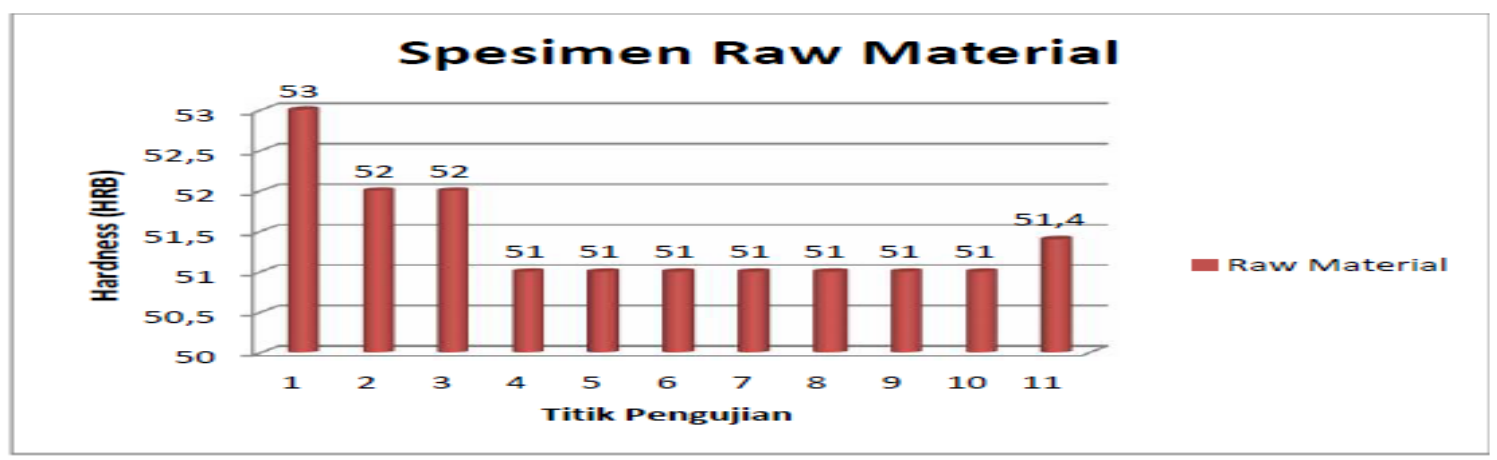

Fig. 5. Graph Of Raw Material Specimens

\subsection{Weld and Hazard Joint Test Specimens with Limestone Media}

The hardness value of the welded joint with limestone media has a high hardness compared to the HAZ section, which has a lower hardness. Because limestone has a thermal conductivity value of $3.897 \mathrm{~W} / \mathrm{m}^{\circ} \mathrm{C}$, this value is greater than the conductivity value of gypsum, which has a low thermal conductivity value of $1.39 \mathrm{~W} / \mathrm{m}^{\circ} \mathrm{C}$. The weld metal has a more complex value than the HAZ value because the more significant the thermal conductivity value, the more complex the metal hardness and the lower the HAZ's hardness.

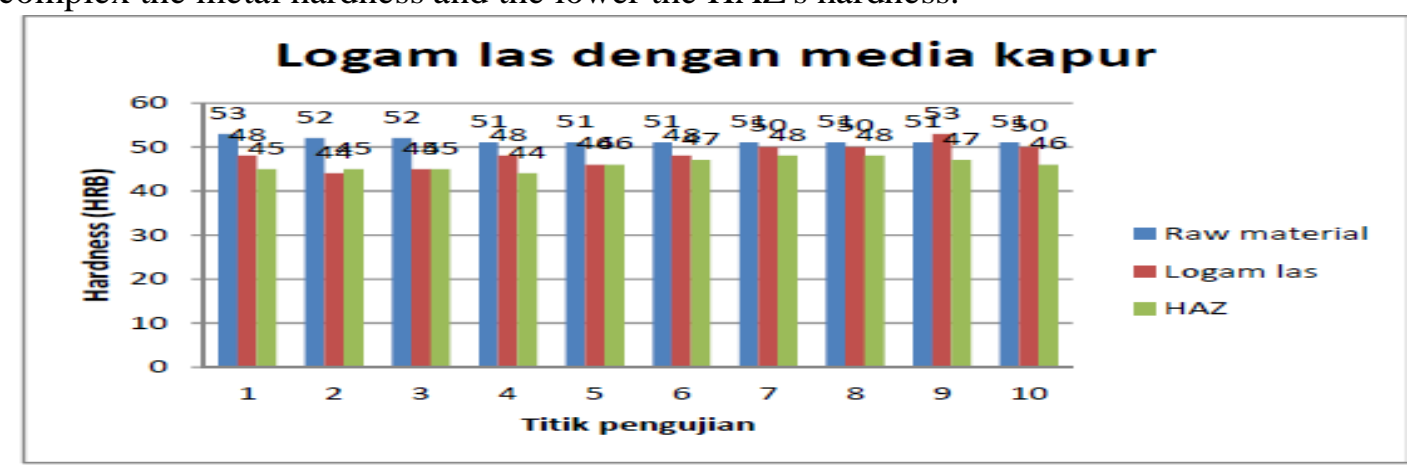

Fig. 6. Graph of Lime Specimens and Limestone HAZ

\subsection{Weld and Hazard Test Specimens with Gypsum Media}

The welded joint's hardness value with gypsum media has a low hardness compared to the HAZ section, which has a high hardness of the welded joint. Gypsum has a thermal conductivity value of $1.39 \mathrm{~W} / \mathrm{m}^{\circ} \mathrm{C}$. This value is lower than the thermal conductivity value of lime which has a thermal conductivity value of $3.897 \mathrm{~W} / \mathrm{m}^{\circ} \mathrm{C}$. The hardness value of the weld metal to be deficient compared to the HAZ value because the lower the conductivity value, the lower the weld metal, and the higher the HAZ value.

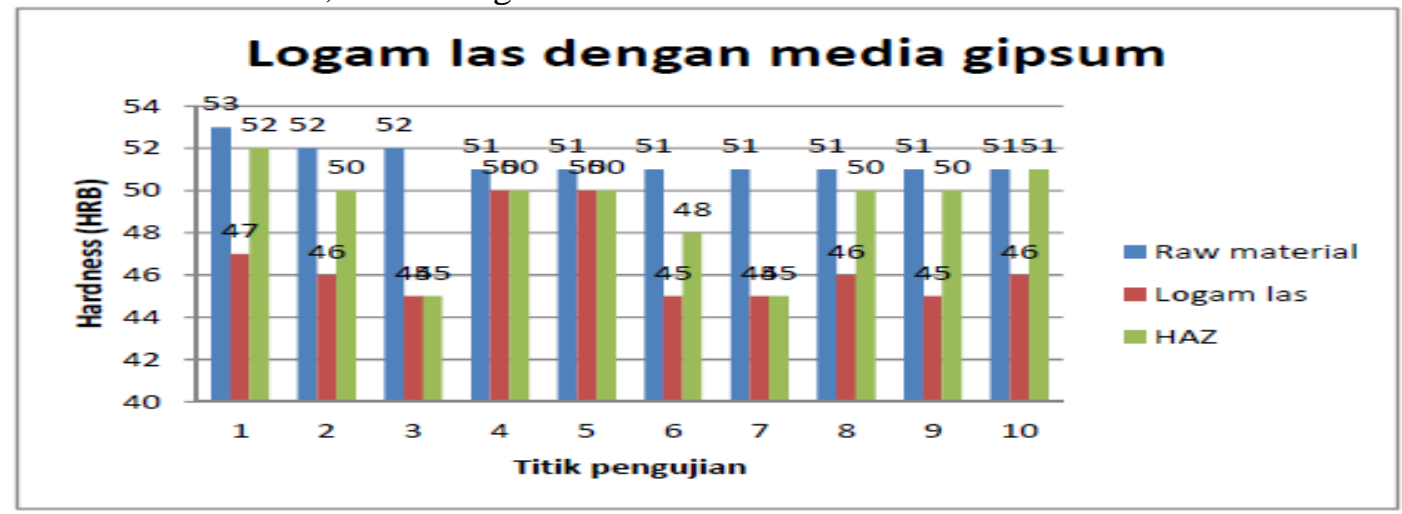

Fig. 7. Graph of Gypsum Specimens and Gypsum HAZ 


\subsection{Welded And HAZ Test Specimens without Cooling Media Treatment}

Even without cooling media such as limestone and gypsum, the media is only air. Still, the atmosphere here has a thermal conductivity value of $0.023 \mathrm{~J} / \mathrm{ms}^{\circ} \mathrm{C}$. The thermal conductivity of air is lower than gypsum by $1,39 \mathrm{~W} / \mathrm{m}^{\circ} \mathrm{C}$ is even lower than the thermal conductivity value of lime which is $3.897 \mathrm{~W} / \mathrm{m}^{\circ} \mathrm{C}$. The weld metal hardness value based on the above statement turns out that the weld metal has a lower value than the HAZ value. Based on the previous explanation, the lower the conductivity value, the softer the weld metal hardness and the higher the HAZ hardness value.

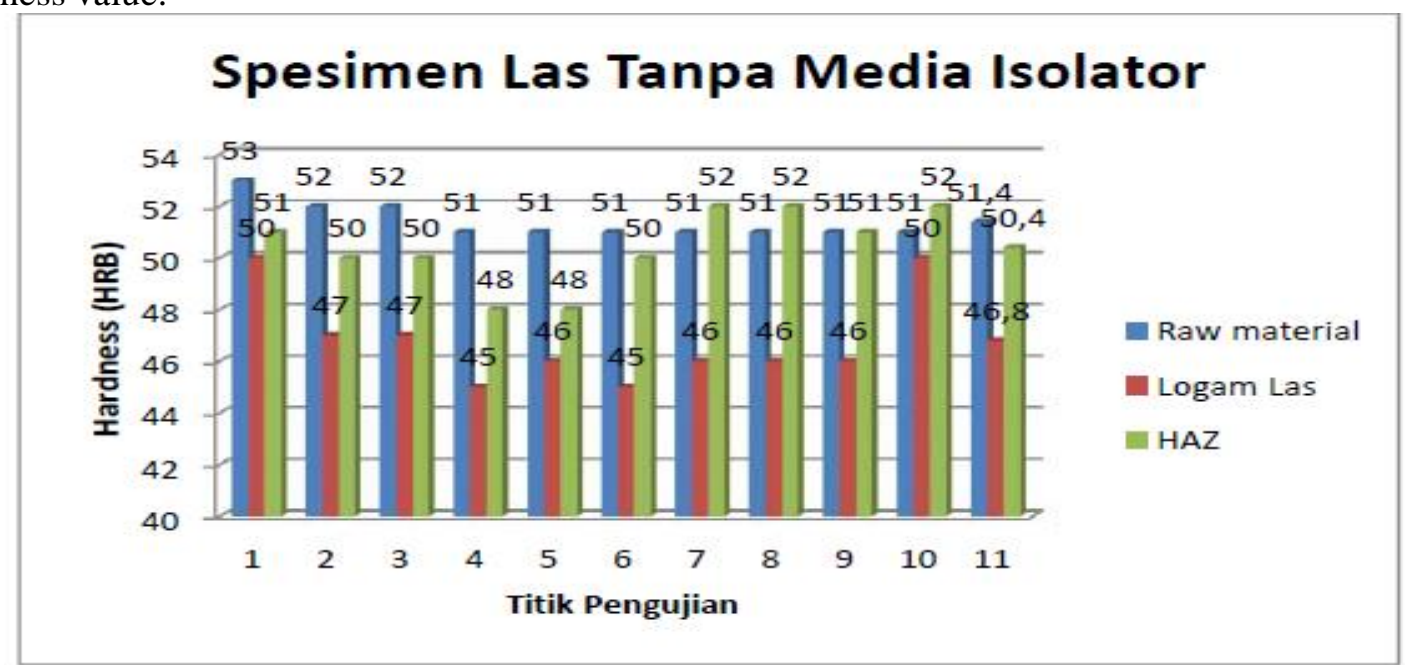

Fig. 8. Graph of Specimens without Cooling Media Treatment

\subsection{Comparison of the Hardness Value of Welding Metal with Limestone and Gypsum Media and Without Isolator Media}

The results of observations and data collection in the explanation above show that the weld metal cooled with lime media turns out to have a harder hardness than gypsum and air media because lime has a thermal conductivity value of $3.897 \mathrm{~W} / \mathrm{m}^{\circ} \mathrm{C}$. In contrast, gypsum has a thermal conductivity value of $1.39 \mathrm{~W} / \mathrm{m}^{\circ} \mathrm{C}$, and air has a thermal conductivity value of $0.023 \mathrm{~J} /$ $\mathrm{ms}^{\circ} \mathrm{C}$. Limestone proves as an excellent insulating material than gypsum and air. The greater the conductivity value of an object, the better the thermal conductivity and the more challenging the weld metal is. If the value of thermal conductivity is lower, the hardness of the metal is getting softer.

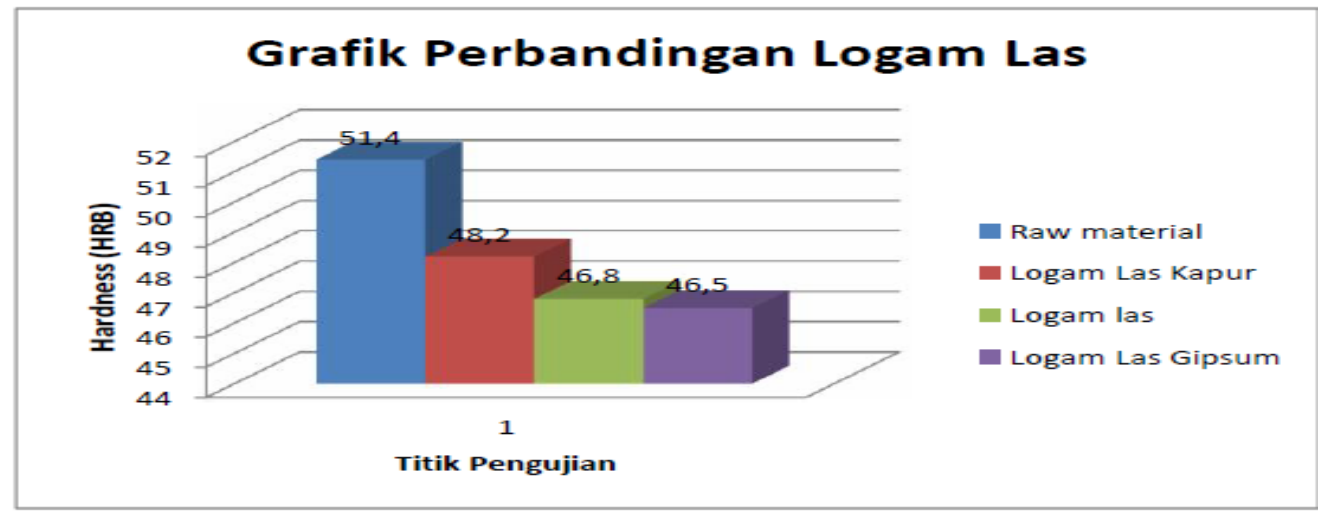

Fig. 9. Graph of weld metal specimens with limestone and gypsum media

4.7 Comparison of HAZ Hardness Value with Lime, Gypsum, and Without Isolator Media

Limestone has a thermal conductivity value of $3.897 \mathrm{~W} / \mathrm{m}^{\circ} \mathrm{C}$ while gypsum has a thermal conductivity value of $1.39 \mathrm{~W} / \mathrm{m}^{\circ} \mathrm{C}$ and air has a thermal conductivity value of $0.023 \mathrm{~J} / \mathrm{ms}^{\circ} \mathrm{C}$. This phenomenon proves that the lower the conductivity value, the softer the hardness of the weld metal. But in the HAZ section, it is evident that the lower the value of the conductivity, the more complex the hardness in the HAZ section. 


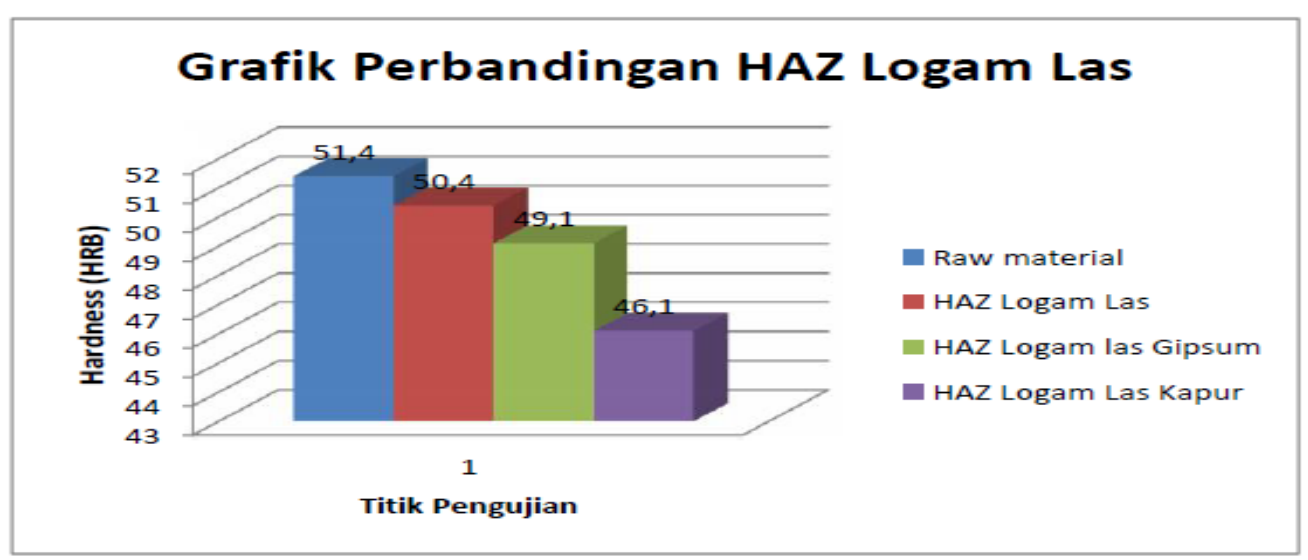

Fig. 10. Graph of HAZ Specimens Using Limestone and Gypsum Media

\section{Conclusion}

The results show that the weld metal cooled with limestone media turned out to have a more challenging attempt than gypsum and air media. Its because limestone has a thermal conductivity value of $3.897 \mathrm{~W} / \mathrm{m}^{\circ} \mathrm{C}$ while gypsum has a thermal conductivity value of 1.39 $\mathrm{W} / \mathrm{m}^{\circ} \mathrm{C}$, and air has a thermal conductivity value of $0.023 \mathrm{~J} / \mathrm{ms}^{\circ} \mathrm{C}$. Limestone is an excellent insulating material than gypsum and air. The greater the conductivity value of an object, the better the thermal conductivity and the more challenging the weld metal is. If the value of thermal conductivity is lower, the hardness of the metal is getting softer.

\section{References}

Anhar, M. (2019). Pendinginan Pengelasan dengan Metode SMAW pada Kekerasan Baja Karbon ST37 dengan Media Serbuk Semen Abu-Abu pada Beban Rockwell 100 kgf. ROTASI, 21(3), 140-146.

Anhar, M., \& Ruchiyat, A. (2020). Pendinginan Pengelasan menggunakan Metode SMAW pada Kekerasan Baja Karbon ST3 dengan Media Serbuk Semen Putih dan Beban Rockwell 100kgf. Jurnal Teknologi dan Rekayasa Manufaktur, 2(2), 39-48.

Budiarsa, I. N. (2008). Pengaruh besar arus pengelasan dan kecepatan volume alir gas pada proses las GMAW terhadap ketangguhan aluminium 5083. Jurnal Ilmiah Teknik Mesin CAKRAM, 2(2), 112-116.

Chandra, Y. (2018). Pengaruh Variasi Holding Time Terhadap Kemampukerasan Baja Menggunakan Alat Uji Jominy. Inovtek Polbeng, 8(2), 257-262.

Helanianto, H. (2017). Pengaruh Perlakuan Temperatur Pemanasan Pada Hasil Pengelasan Metode Smaw Terhadap Hardness Logam Induk Dan Logam Las. Jurnal Sistem Teknik Industri, 19(1), 30-33.

Ruchiyat, A., Anhar, M., Yusuf, Y., \& Polonia, B. S. E. (2019). The Effect Of Heating Temperature On The Hardness, Microstructure And V-Bending Spring Back Results On Commercial Steel Plate. Journal of Applied Engineering and Technological Science (JAETS), 1(1), 1-16.

Zulhafril, H., Jasman, J., \& Tespoer, K. J. (2020). The Effect of Cooling Media on Tensile Strength of Medium Carbon Steel in Post Welding Process Using Electric Welding (SMAW) with E7018 Electrodes. Teknomekanik, 3(2), 62-69.

Zulkifli, Z., Dahlan, B., \& Fatimah, N. (2020). Analisa Pengaruh Variasi Media Pendingin Terhadap Kekuatan Mekanik Pada Hasil Pengelasan Metode Smaw Material Baja St 52. Journal of Welding Technology, 1(2), 48-51. 